\title{
A Brief Environmental Analysis of Tourism and Hotel Industries and their Impact on Nepalese Base Structure
}

$\sim$ Govinda Bahadur Karki, MPhil $^{1}$

\begin{abstract}
This brief academic research paper deals with the evolution and present status of tourism and hotel industry in Nepal. It also incorporates the description about tourism business enterprises, about hotel industries, legal and regulatory framework, and contribution of tourism and hotel industries in country's Gross Domestic Product and the impact of tourism and hotel industries on socio-cultural, economic, political and cultural sectors. The basic thrust of this research paper to analyze environmental/ opportunities analysis of tourism and hotel industries as per the rules, policies and market structures. Domestic and global tourism is now generally considered as one of the largest industries in the world and one of the most significant sources of employment and GDP.
\end{abstract}

Key Words: Tourism, Hotel Industry, Nepalese Base Structure, Tourism

\section{Evolution of Tourism in Nepal}

Tourism sector has not been turned into an industry without facing hurdles due to some geographically uneven shaped areas and politically unfavorable situation for the long past. Satyal says that since ancient times Nepal was known as the abode of Gods, many Chinese and Indian people came to Nepal to make long pilgrimage to the places of venerated worship. (Satyal, 2004:30) In addition to this, there were other forms of journeys particularly some commercial trips, exchange of envoys to maintain friendly relation at the political level. Such type of tourism though couldn't provide much commercial importance over the period, laid milestones for the further development and publicity. Hence, such type of development can be regarded as ancient tourism.

The democratic revolution of 1951-52 was a boon for Nepalese tourism. Nepalese people got liberty. With this liberty, foreigners got an opportunity of visiting

1 Karki is the Campus Chief of Koteshwor Multiple Campus (KMC). He teaches poetry, plays, prose to the students of Bachelor-level at KMC. Also, he heads the Quality Assurance and Accreditation (QAA) division, and is one of the member of the advisory board of KMC research Journal. 
Nepal. It was a great leap bound in tourism sector. Tourism has a very short history though it has witnessed the visits of various travelers and saints in earlier days of civilization. Therefore, it is clear that tourism in Nepal in its modern form was started only in the fifties after the dawn of democracy resulting on an open door policy for the tourists and visitors (ESCAP, 1991:194 and FNCCI, 1996:12) from all over the world.

Nepal extended bilateral and multilateral relations by establishing diplomatic missions and by getting membership of United Nations Organizations, SAARC and other regional organizations. Similarly, Nepal became the member of International Union of Official Travel Organization and other UN agencies. Because of this, Nepal's identity and publicity was spread all over the world. In addition to this Mountaineering and other expeditions and pleasure tours highlighted the importance of Nepalese land for all kinds of tourists of all countries and domestic tourists too. International tourists spread the name of Nepal as the land of Mount Everest ,the birth place of Lord Gautam Buddha,the third pole of the earth and the home of gallant Gorkhas to each and every corner of the world( Satyal,2004:33, FNCCI,1996:9). The report of MOTCA disclosed that tourism gradually, became one of the most important segments of the Nepalese economy(MOCTA,1998:9).

Similarly, Rudra Prasad Upadhyaya says that it is found to be continuously growing over the years. Though it has witnessed some fluctuations during the review period (1966-2005),it sustained the growth and became the leading sector of the economy( Upadhyaya,2001:247).The sustained growth of tourism over the period can be attributed to the involvement of public and private sector in different infrastructure development and promotional activities.

\section{Literature Review}

\subsection{Growth in Tourism: A Brief Empirical Analysis}

As Nepal is a fertile land for the tourists, the trend of visiting Nepal is satisfactory. The following table shows the growth in tourism.

Nowadays, tourism has emerged as one of the few encouraging sectors of the Nepalese economy. The report of IBRD says that Nepal is endowed with beauty, and the very terrain that impedes other economic development is one of the world's greatest tourist spectacles. From the slow beginning in the late 1950 s, modern domestic and international tourism has become a governmentencouraged industry, which by the late 1970s stood as a Nepal's number one source of foreign exchange (IBRD, 1979); one of the most lucrative attractions for Nepalese private investment (Balkie et all.1980).

Smith highlights the fact for the increment of tourists that government policies 
played an important role for the boom situation through some important actions such as loosening of visa policies; the opening of previously restricted mountain areas to trekking; development of National Park System, investment in the creation and continual improvement of an international airport; providing loans for hotel and restaurant development; and permitting of gambling in an international hotels( Smith,1981).

National Planning Commission Secretariat released a report in 1979 and that report stated that six airlines fly into Kathmandu, and seven resort town beneath the Annapurna peaks , the number of hotels increasing there from five in 1968, to thirty-four in 1974, and the number of tourists growing from a few hundred a year in the early 1960 s to 3,000 in 1970 to 7,000 in the peak season of 1974 . Tourism is said to employ some 200,000 people in 1980 directly or indirectly (Singh,1981),far more than in any sector of the economy except agriculture.

\section{Table -1}

TABLE 2.1: TOURIST ARRIVAL AND AVERAGE LENGTH OF STAY, 19

\begin{tabular}{|l|c|c|c|c|c|c|}
\hline \multirow{2}{*}{ Year } & \multicolumn{2}{|c|}{ Total } & \multicolumn{2}{c|}{ By Air } & \multicolumn{2}{c|}{ By Land } \\
\cline { 2 - 7 } & Number & $\begin{array}{c}\text { Annul Growth } \\
\text { Rate (\%) }\end{array}$ & Number & Pereent & Number & Percent \\
\hline 1964 & 9,526 & 30.9 & 8,435 & 88.5 & 1,091 & 11.5 \\
\hline 1965 & 9,388 & -1.4 & 8,303 & 88.4 & 1,085 & 11.6 \\
\hline 1966 & 12,567 & 33.9 & 11,206 & 89.2 & 1,361 & 10.8 \\
\hline 1967 & 18,093 & 44.0 & 15,064 & 83.3 & 3,029 & 16.7 \\
\hline 1968 & 24,209 & 33.8 & 19,717 & 81.4 & 4,492 & 18.6 \\
\hline 1969 & 34,901 & 44,2 & 28,130 & 80.6 & 6,771 & 19.4 \\
\hline 1970 & 45,970 & 31.7 & 36,508 & 79.4 & 9,462 & 20.6 \\
\hline 1971 & 49,914 & 8.6 & 40,369 & 80.9 & 9,545 & 19.1 \\
\hline 1972 & 52,930 & 6.0 & 42,484 & 80.3 & 10,446 & 19.7 \\
\hline 1973 & 68,047 & 28.6 & 55,791 & 82.0 & 12,256 & 18.0 \\
\hline 1974 & 89,838 & 32,0 & 74,170 & 82.6 & 15,668 & 17.4 \\
\hline 1975 & 92,440 & 2.9 & 78,995 & 85.5 & 13,445 & 14.5 \\
\hline 1976 & 105,108 & 13.7 & 90,498 & 86.1 & 14,610 & 13.9 \\
\hline 1977 & 129,329 & 23.0 & 110,180 & 85.2 & 19,149 & 14.8 \\
\hline 1978 & 156,123 & 20.7 & 130,034 & 83.3 & 26,089 & 16.7 \\
\hline
\end{tabular}




\begin{tabular}{|l|l|l|l|l|l|l|}
\hline 1979 & 162,276 & 3.9 & 137,865 & 85.0 & 24,411 & 15.0 \\
\hline 1980 & 162,897 & 0.4 & 139,387 & 85.6 & 23,510 & 14.4 \\
\hline 1981 & 161,669 & -0.8 & 142,084 & 87.9 & 19,585 & 12.1 \\
\hline 1982 & 175,448 & 8.5 & 153,509 & 87.5 & 21,939 & 12.5 \\
\hline 1983 & 179,405 & 2.3 & 152,470 & 85.0 & 26,935 & 15.0 \\
\hline 1984 & 176,634 & -1.5 & 149,920 & 84.9 & 26,714 & 15.1 \\
\hline 1985 & 180,989 & 2.5 & 151,870 & 83.9 & 29,119 & 16.1 \\
\hline 1986 & 223,331 & 23.4 & 182,745 & 81.8 & 40,586 & 18.2 \\
\hline 1987 & 248,080 & 11.1 & 205,611 & 82.9 & 42,469 & 17.1 \\
\hline 1988 & 265,943 & 7.2 & 234,945 & 88.3 & 30,998 & 11.7 \\
\hline 1989 & 239,945 & 53.7 & 207,907 & 86.6 & 32,038 & 13.4 \\
\hline 1990 & 254,885 & 6.2 & 226,421 & 88.8 & 28,464 & 11.2 \\
\hline
\end{tabular}

TABLE 2.1: 'TOURIST ARRIVAL AND AVERAGE LENGTH OF STAY, 1964-2016 (contd.)

\begin{tabular}{|c|c|c|c|c|c|c|c|}
\hline \multirow[b]{2}{*}{ Year } & \multicolumn{2}{|c|}{ Total } & \multicolumn{2}{|c|}{ By Air } & \multicolumn{2}{|c|}{ By Land } & \multirow{2}{*}{$\begin{array}{c}\text { Average } \\
\text { Length of Stay }\end{array}$} \\
\hline & Number & $\begin{array}{l}\text { Growth } \\
\text { Rate }(\%)\end{array}$ & Number & Percent & Number & Percent & \\
\hline 1991 & 292,995 & 15,0 & 267.932 & 91.4 & 25,063 & 8.6 & 9.25 \\
\hline 1992 & 334,353 & 14.1 & 300,496 & 89.9 & 33,857 & 10.1 & 10.14 \\
\hline 1993 & 293,567 & -12.2 & 254,140 & 86.6 & 39,427 & 13.4 & 11.94 \\
\hline 1994 & 325,531 & 11.2 & 289.381 & 88.6 & 37.150 & 11.4 & 10.00 \\
\hline 1995 & 363,395 & 11.3 & 325,035 & 89.4 & 38,360 & 10.6 & 11.27 \\
\hline 1996 & 393,613 & 8.3 & 343,246 & 87.2 & 50,367 & 12.8 & 1350 \\
\hline 1997 & 421,857 & 7.2 & 371,145 & 88.0 & 50,712 & 12.0 & 10.49 \\
\hline 1998 & 463,684 & 9.9 & 398,008 & 85.8 & 65,676 & 14.2 & 10.76 \\
\hline 1999 & 491,504 & 6.0 & 421,243 & 85.7 & 70,261 & 14.3 & 12.28 \\
\hline 2000 & 463,646 & $-5,7$ & 376,914 & 81.3 & 86,732 & 187 & 11.88 \\
\hline 2001 & 361,237 & 22.1 & 299,514 & 829 & 61,723 & 17.1 & 11.93 \\
\hline 2002 & 275,468 & -23.7 & 218,660 & 79.4 & 56,808 & 20.6 & 7.92 \\
\hline 2003 & 338,132 & 22.7 & 275,438 & 81.5 & 62,694 & 18.5 & 9.60 \\
\hline 2004 & 385,297 & 13.9 & 297,335 & 77.2 & 87,962 & 22.8 & 13.51 \\
\hline 2005 & 375,398 & -2.6 & 277,346 & 73.9 & 98,052 & 26.1 & 9.09 \\
\hline 2006 & 383,926 & 2.3 & 283,819 & 73.9 & 100,107 & 26.1 & 10.20 \\
\hline 2007 & 526,705 & 37.2 & 360,713 & 68.5 & 165,992 & 31.5 & 11.96 \\
\hline
\end{tabular}




\begin{tabular}{|l|c|c|c|c|c|c|c|}
\hline 2008 & 500,277 & -5.0 & 374,661 & 74.9 & 125,616 & 25.1 & 11.78 \\
\hline 2009 & 509,956 & 1.9 & 379,322 & 74.4 & 130,634 & 25.6 & 11.32 \\
\hline 2010 & 602,867 & 18.2 & 448,800 & 74.4 & 154,067 & 25.6 & 12.67 \\
\hline 2011 & 736,215 & 22.1 & 545,221 & 74.1 & 190,994 & 25.9 & 13.12 \\
\hline 2012 & 803,092 & 9.1 & 598,258 & 74.5 & 204,834 & 25.5 & 12.16 \\
\hline 2013 & 797,616 & -0.7 & 594,848 & 74.6 & 202,768 & 25.4 & 12.60 \\
\hline 2014 & 790118 & -0.9 & 585981 & 74.2 & 204137 & 25.8 & 12.44 \\
\hline 2015 & 538970 & 0.32 & 407412 & 75.6 & 131558 & 24.4 & 13.16 \\
\hline 2016 & 753002 & 40 & 572563 & 41 & 180439 & 37 & 13.4 \\
\hline
\end{tabular}

\section{CHART 2.1: TOURIST ARRIVAL IN NEPAL 2007-2016}

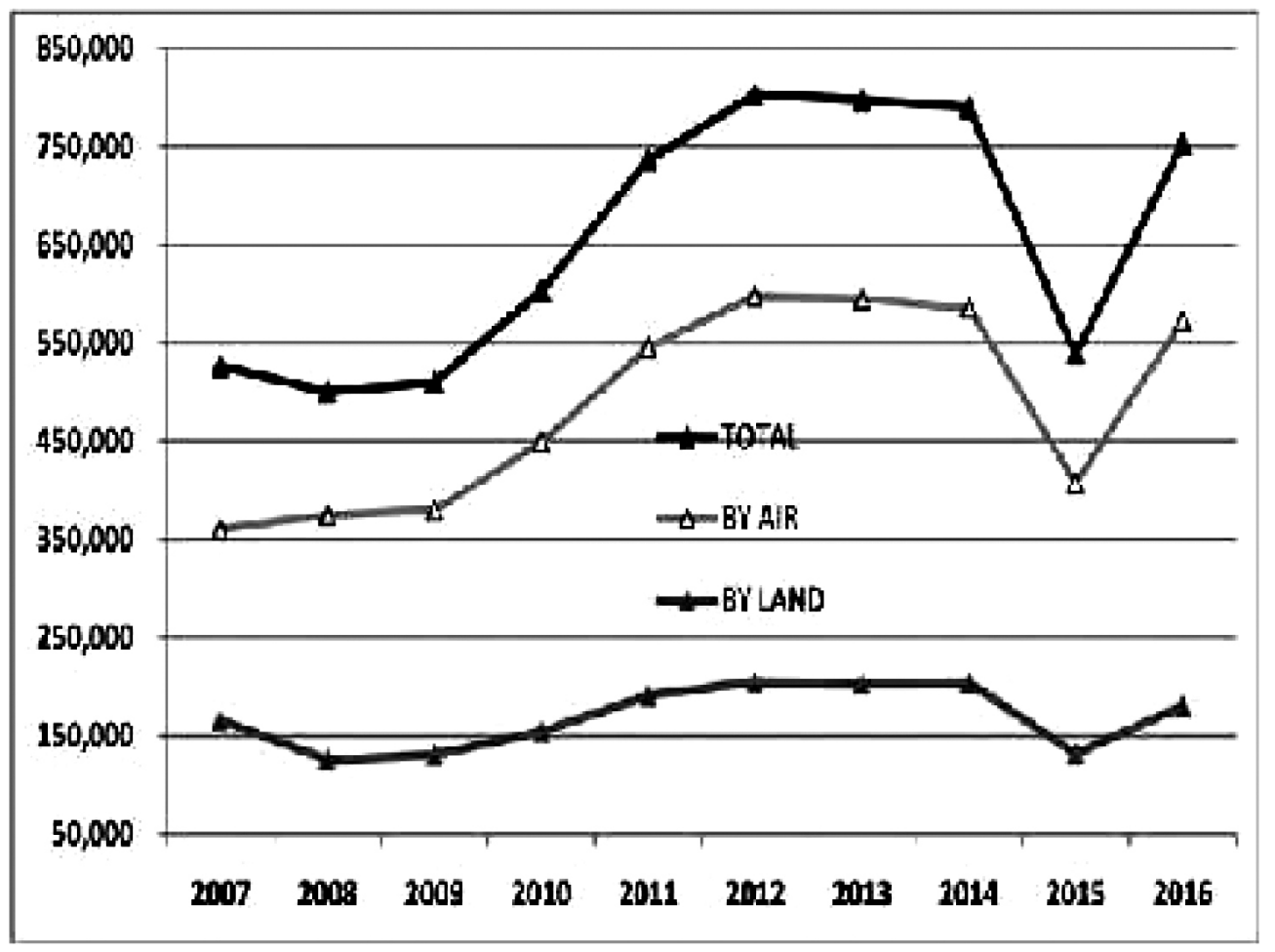

This above table depicts the development of tourism in Nepal. The number of tourists have gradually been increasing over the period. In Fiscal Year 1965/66 ,only 9,211 foreign tourists ( except Indian tourists) had visited Nepal. The number reached to 90,431 in F.Y.1974/75164,380 in F.Y.1974/75 and so on. The number reached to the maximum at 477,774 in F.Y.1998/99. However the trend showed a major setback in arrival starting from 2000. In F.Y.1992/2000, the number decreased .The major reason behind this was 
over-spreading terrorism around the world and Maoist insurgency inside the country. Afterwards; it has shown some improvements at slower pace and reached to 295,679 and 388,043 during F.Y.2002/03 and 2003/04 respectively. However, during F.Y.2004/05 it again witnessed a decline of 23.8 percent and limited only in 295,611(MOTCA, 1998).

\subsection{Hotel Industry: A Brief Empirical Analysis}

Hotels and Resorts are classified as industry receiving national priority and enjoying the facilities as well as incentives as per the provision of Industrial Enterprise Act, 1992.Other tourism services are also entitled to receive facilities based on value added, and employment generation. Similarly, they are entitled to get duty concessions on the import of specified products based on working capital and plans and services on priority basis for communication equipment, electricity and water supply. In 1992, Government of the then time summarized the issue that in addition, hotel, restaurant resorts, and other tourism services would be entitled for the specified facilities and incentives based on their opening and operation in the rural areas specified the government (HMG/N, 1992).

Hotel Industry is one of the tourism business enterprises .In order to provide the details about the requisites of a tourism industry ,United Nations and World Tourism Organization have developed the Standard Classification of Tourism Activities (SICTA). SICTA classifies the tourism industry in primary, secondary and tertiary sectors.

\section{Table-2}

This table presents the data of tourism business enterprises.

\begin{tabular}{|c|c|c|c|c|c|c|}
\hline Year & $\begin{array}{c}\text { No. of } \\
\text { hotels } \\
\text { and } \\
\text { resorts }\end{array}$ & $\begin{array}{c}\text { No. of } \\
\text { Travelers }\end{array}$ & $\begin{array}{c}\text { No. of } \\
\text { Trekking }\end{array}$ & $\begin{array}{c}\text { No. of } \\
\text { rafting }\end{array}$ & $\begin{array}{c}\text { No. of Hotels, } \\
\text { Travels, } \\
\text { Trekking and } \\
\text { Rafting }\end{array}$ & $\begin{array}{c}\text { No of } \\
\text { Hotels } \\
\text { Beds }\end{array}$ \\
\hline 1980 & 73 & - & - & - & 73 & 5,109 \\
\hline 1985 & 80 & - & - & - & 80 & 6,910 \\
\hline 1990 & 168 & 145 & 139 & 17 & 496 & 10,244 \\
\hline 1995 & 520 & 386 & 310 & 67 & 1,283 & 21,807 \\
\hline 2000 & 848 & 637 & 537 & 87 & 2,109 & 34,958 \\
\hline 2001 & 888 & 691 & 580 & 87 & 2,246 & 36,163 \\
\hline 2002 & 943 & 738 & 611 & 87 & 2,379 & 37,616 \\
\hline
\end{tabular}




\begin{tabular}{|l|c|c|c|c|c|c|}
\hline 2003 & 966 & 788 & 645 & 90 & 2,489 & 28,270 \\
\hline 2004 & 996 & 877 & 705 & 91 & 2,669 & 39,107 \\
\hline 2005 & 1,006 & 948 & 740 & 92 & 2,786 & 39,384 \\
\hline
\end{tabular}

Source: Economic Survey (various issues)

To promote tourism the primary prerequisite for this is to manage hotels and beds. Thus, they are the tourism business enterprises. The above table shows the development trend of number of hotels, number of trekking, number of rafting, and number of hotel beds in the Fiscal Year 1980 to 2005 BS.There seems to be natural growth especially in number of hotels and resort and beds.

\section{Tourism Policy and Plans: A Brief Empirical Analysis}

Institutional good governance is necessary to flourish any organizations and industry. Supremacy of law, rules and regulations and implementation strictly is the need of time so as to streamline the institute in the right tract. Plan and systematic way of conducting any enterprises is inevitable. Even tourism sector should not be the exception for this. So far as tourism planning and rule of law are concerned, Nepal's tourism planning in its initial form was concerned; its initial form was initiated in 1966. It has provided with the systematic classification of tourism. It was called ' Tourism Business Environment Analysis'.Later,it was followed by Nepal Tourism Master Plan 1972,designed to cover initially for 10 years. In 1957, Nepal has established 'Tourism Development Board' to look after and to systematize this sector as per the rules and regulations.

Considering tourism sector as one of the important economic sectors in Nepal, the then government of Nepal prepared and implemented 'Nepal Tourism Master Plan' in 1972. It became the milestone to uplift and promote tourism and hotel industry in systematic way. In the same way, Nepal Tourism Marketing Strategy was launched in the year 1976 to 1981. Tourism Policy was developed in 1995. The underlying theme of this policy is that the private sector participation shall be highly encouraged in the development and expansion of tourist activities. Existing tourism infrastructures and facilities will be upgraded. Similarly, due attention will be paid to improving regional imbalances while developing tourism industry and its enterprises. This policy has also highlighted the significance of linkages of tourism and agro-based sectors for their sustainability.

Industrial Enterprises Act,1992 made the legal provision that hotels and resorts are also classified as industry. So, the entrepreneurs who are involved in this sector are free to follow the industrial provisions and systems. The Constitution of Nepal, 2072, Part 4, Article 51 (1) clearly states the State's Policy regarding the development of tourism and its enterprises. This Article states that to develop 
eco-friendly tourism industry as an important base of national economy by way of identification, protection, promotion and publicity of the ancient, cultural, religious, archeological and natural heritages of Nepal, to make the environment and policy required for the development of tourism,culture, and to accord priority to local people in the distribution of benefits of tourism industries'. (Constitution, 2072:42)

Whatever the efforts are made by the government and related organizations for the development, promotion and protection of tourism and its enterprises show that the business in this sector is secured and very important, profit-oriented to the aspirants.

\section{Conceptual Framework}

Tourism and its enterprises are understood as the complex and multidisciplinary nature, so efforts are required to identify the business market environment. The analysis helps to clarify the components affecting competitiveness, pointing out the present performance and enforce the comprehension of the necessity for adaptations. Different models are available to describe the tourist environment. Such analyses, according to Fyall and Garrod, examine environmental factors, which can not be controlled, creating both opportunities and threats to a destination (Fyall and Garrod, 2005).

The PEST model includes Political, Environmental, Social, and Technological forces, which have to be considered from a tourism stand-point. The question, how do political forces, e.g. employment and environmental law, foreign trade agreements or monetary and fiscal policy, inflation and exchange rates; socialcultural factors e.g. age groups, family structures, income distribution and education level ; and technological factor e.g. internet expansion ,computerized reservation systems or production technology affect the tourism and hotel industry?

Another approach, conducted by Butler (1980), utilizes the application of the product life-cycle to tourism. The basic idea here is that a destination or tourism product goes through the following five phases of development: introduction, growth, maturity, saturation and decline. Each phase has to adapt to changing modes in characteristics like visitor numbers; price of service; accommodation capacity; image and attractions or expenditure per capita. The mentioned changes require a customized marketing response and strategic foresight in such a way that the marketing target changes from awareness to persuasion; that the product matures from basic to good via improvements or simply changes in the price.

There is another important model i.e. Global Forces Model which presents global arranged in three different layers (Ritchie et al., 2003) surrounding the tourist 
destination in the middle. The closer to the centre the more unsteady the forces are and the most directly they affect a destination is performance and well-being. The forces can not be reviewed in isolation since there is no clear dividing line between the single layers. The three layers respectively are: i) the inner layer, ii) intermediate level, and iii) outer level.

The inner layer is characterized by its high instability and short changing time. Its three components consisting of technological, political, and economic forces affect a destination's success instantaneously. The intermediate level in comparison to the inner level more stable and predictable but not of more or less importance. The main focus is stressed on value system, languages, and attitudes towards work, food preparation and delivery system. The third and most important thing is the outer layer. It basically stresses on the required changes in the tourism and hotel industry, right and time-tested decisions made by management level.

\subsection{SWOT Analysis}

In order to make a current market situation and draw a marketing plan it is a common habit to undertake a SWOT analysis. Here, both internal and external factors reviewed and classified according to their importance on a company's market situation.

\subsection{Marketing Opportunity Analysis: A Critical Outlook on it}

To run or expand hotel industries top level managers should be aware of macro environmental trend and forces. Top level managers should effectively prepare corporate and division strategic planning, business unit strategic planning. Organizational objective and policy should be set and organizational resources and structure should be prepared. Marketing decisions must relate to broader company goals and strategies. Consumer oriented strategies should be adopted. To be successful, a company must satisfy needs and wants of consumers better than competitors.

Opportunity is a favorable condition in the environment .Market is the source of opportunities, successful managers must understand market opportunities. Similarly, business unit strategic planning is another important tool to observe the company. A manager should consider and determine business composition, develop objectives and should conduct strategic analysis of business unit.

Considering above theoretical assumptions, Nepal has lots of opportunities to uplift the economy through development of tourism industry. People in tourism business, industry and even other stakeholders are of the view that marketing environmental /opportunities of hotel industry in Nepal are not so congenial. Soaltee Hotel has decided to expand its branches to Nepalgunj and Pokhara. 
Other hotels and travel agencies have made plan to expand their branches in different tourism area of Nepal. On the other hand an international chain hotel Sheraton Hotel decided to enter Nepalese market very recently. At this juncture, the brief research report depicts the fact that Nepalese past efforts made to develop tourism industries and its enterprises and legal provisions all are very favorable to expand and flourish the tourism business. The above mentioned tables also prove that the tourists visiting Nepal are in increasing ratio except in those years when Nepal was facing the crisis of internal war.

Industrial Enterprises Act, 1992 has already categorized hotel and restaurant sectors as industry. Thus, industry can maximize the profit as well as value. For international business, Nepal is about to sign on the agreement of Bilateral Investment Protection and Promotion Agreement (BIPPA) in bilateral level to ensure protection and guarantee of business. But such agreement should be held on win-win situation but not only to dominate smaller country. It creates favorable environment for the businessman.

Present Constitution of Nepal, The Constitution of Nepal, 2072, also states the one of the national policies of developing Eco-friendly tourism industry as an important base of national economy. Nepal Government guarantees protection and for the promotion and publicity of tourism industry and its stakeholders. Nepal Tourism Master Plan, policies and other act and regulations support to carry on this business in Nepal. The political environment is also being changed and after successful three- phased election, Nepal is entering into the path of political stability by overcoming decade's long political turmoil or anarchic situation.

Now, Nepal has three layers of government: local level, provincial level and federal level. Every province and local level government pay attention for the promotion of tourism sector. They manage supportive environment for this business sector. Anyway the managers should consciously analyze, observe and give reasons by using proven standards of this sector. They have to make detail study of PEST Models and other models in prior basis. Similarly, SWOT analysis is the heart of any organization. At least basic needs have been fulfilled and means of connectivity are also easily available. Nepal is geographically too, is in favorable place. At least, if we will be able to welcome even one percent of population of our immediate neighbor, there will be drastic development in tourism and its main stakeholders hotel industry sectors. This situation is very possible if we will be able to manage environmental aspects of our country. Nepal's climatic condition is unique which attracts the tourists. Nepal is the country of Mount Everest, birth place of Gautama Buddha, and natural flora and fauna are our significant indexes to attract tourists both internal and external. 


\section{General Impact of Tourism and Hotel Industries}

Especially Revenue Generated by this sector. Tourism is one of the most important revenue generating sector of Nepal. From this sector directly and indirectly thousands of people are employed. It helps to eradicate the poverty. Primary sector, secondary sector and tertiary sector are running smoothly because they are interrelated. Nepal's literacy rate is also being increased gradually. Nepal is crawling to the path of economic prosperity. A human Development Index report show that Nepal is increasing its rank. Nepal's per capita income is also increased. Road network is linked in every district.

Tourism industry is now considered as efficient tools for promoting economic growth. The contribution of tourism can be explained with various methods depending upon the motive of such analysis. The prominent contribution of the tourism is economic benefits followed by socio-cultural and direct, indirect and induced effects in other sectors of the economy.

\section{Conclusion}

This research work aims at analyzing Nepal's opportunity in tourism industry under the assumptions that the identified results are utilized for the promotion and expansion of tourism and hotel industries sectors. Starting with brief historical aspects the research paper concludes that environmental aspect for tourism and hotel industries sectors are congenial and managers have to apply different marketing tools to reach to the target.

\section{References}

Blaikie, Piers, John Camron, and David Seddon,1980.Nepal in Crisis: Growth and Stagnation at the Periphery. Oxford: Claredon Press.

ESCAP (2001). Opportunities and Challenges for Tourism Investment, ESCAP Tourism Review No.21.New York: United Nations.

ESCAP(1991).Investment and Economic Cooperation in the Tourism Sector in Developing Asian Countries. Report of a Seminar Organized by ESCAP Bankok,5-21October 1991.Tokyo and Sendai Japan.

FNCCI(1996).Directory of Tourism. Kathmandu: Tourism Committee Federation Nepalese Chambers of Commerce and Industries.

Fyall,A.Garrod,B.(2005).Tourism Marketin:A Collaborative Approach. UK, USA, Canada: Channel View Publications.

Gaige, Fredrick H. (1975). Regionalism and National Unity in Nepal. Berkeley: University of California Press. 
HMG/N (1992). Industrial Enterprise Act,1992. Kathmandu:Ministry of Law and Justice,His Majesty's Government of Nepal.

Horenbein,Thomas F.(1996).Everest the West Ridge.New York:Sierra Club/Ballantine. Maharjan,Narayan P.(2004). Tourism Planning in Nepal.A Ph.D. Thesis Submitted to Faculty of Management, Tribhuvan University Kathmandu, Nepal.

MOTCA(1998). Nepal Tourism Statistics, 1997. Kathmandu:His Majesty's Government of Nepal,Ministry of Tourism and Civil Aviation.

National Planning Commission Secretariat (1979).Basic Principles of the Sixth Plan(1980-1985).Kathmandu,Nepal: His Majesty's Government Press.

Regmi,Mahesh C.(1963).Land Tunere and Taxation in Nepal,Vol.Berkeley:University of California Press.

RiJtchie,JR.B. Crouch,G.I.Ritchie,J.R.(2003). The Comparative Destination:A Sustainable Tourism Perspective.UK,CABI Publishing.

Singh,Kedar Man.(1981).Not Yet Cleared for Take-Off.Far Eastern Economic Review,113-130.

Smith, Valene I.(1981). Controlled Vs. Uncontrolled Tourism: Bhutan and Nepal.Royal Anthropological Institute News 46:4-6.

Upadhyaya,Rudra Prasad (2001). A Study of Tourism as a Leading Sector in Economic Development in Nepal. A Ph.D. Thesis submitted to Department of Economics,University of Lucknow, India. 